Int. J. Electrochem. Sci., 15 (2020) $7013-7026$

International Journal of

ELECTROCHEMICAL

SCIENCE

$\underline{\text { www.electrochemsci.org }}$

\title{
Optimization of Cathodic Protection System for River-Crossing District Heating Pipeline using Computational Analysis: Part I. The Basic Model
}

\author{
Min-Sung Hong ${ }^{1}$, Young-Shin Jeon ${ }^{2}$, Woo-Cheol Kim², Joon Cheol Jeong ${ }^{2}$, Jung-Gu Kim ${ }^{1, *}$ \\ ${ }^{1}$ School of Advanced Materials Engineering, Sungkyunkwan University, 300 Chunchun-Dong, \\ Jangan-Gu, Suwon 440-746, South Korea; \\ ${ }^{2}$ Frontier Research \& Training Institute, Korea District Heating Corporation, 92 Gigok-ro, Yongin, \\ Gyeongi 17099, South Korea \\ *E-mail: kimjg@ @kku.edu
}

doi: $10.20964 / 2020.07 .80$

Received: 18 February 2020 / Accepted: 9 April 2020 / Published: 10 June 2020

In this case study, we optimized cathodic protection (CP) design for river-crossing district heating (DH) pipeline under the Han River. This pipeline is not electrically insulated with other adjacent pipelines. Therefore, additional consideration for CP current loss to connected pipelines at both sides (North and South side) is needed. Furthermore, there are some limitations on anode installation. For these reasons, computational analysis of $\mathrm{CP}$ design was performed considering environmental factors. The minimum current for $\mathrm{CP}$ of river-crossing $\mathrm{DH}$ pipeline was found to be $100 \mathrm{~A}$, although theoretical calculation result was $74 \mathrm{~A}$. This might be due to the following three reasons. First, the distance of the center area is too far from both anode groups. Second, electrically connected south/north pipe can absorb some CP current. Third, the three pipelines are too close to each other. Thus, incorporating practical corrosion properties of metal and environmental factors in the computational analysis can improve the reliability of CP design for a pipeline.

Keywords: Cathodic Protection; District Heating; Potentiodynamic Polarization test; Computational Analysis; River-Crossing Pipeline

\section{FULL TEXT}

(C) 2020 The Authors. Published by ESG (www.electrochemsci.org). This article is an open access article distributed under the terms and conditions of the Creative Commons Attribution license (http://creativecommons.org/licenses/by/4.0/). 